\title{
Rentier state as an obstacle to development in the Middle East
}

Andrzej GUZOWSKI, University of Warsaw

\begin{abstract}
$M$ any Middle Eastern countries, especially the ones in Arabian Peninsula, are well-known for being rich with oil and gas. While it could be considered a blessing by many, it is becoming more and more apparent that the abundance of natural resources in the region is a double-edged sword and a form of a natural resource trap. Many countries have become so-called "rentier states", funding their operations and their very structures by renting their resources to external actors. While it may seem like a profitable political move at first, said overreliance conserved the structure of economies in the Middle Eastern, never forcing the countries to develop effectively, thus making most of the produced goods, other than oil and gas, uncompetitive on the international market. Long term, it may prove disastrous for the Middle East as eventually the resources are going to get exhausted and said countries will be left with nothing but an economic structure unadjusted to the $21^{\text {st }}$ century.
\end{abstract}


$\mathrm{O}$ il has long been called "the black gold". Along with natural gas it has been one of the most important energy sources in the world in the last decades and has served as a necessary tool to economic growth in many countries. With the oil prices having long been on the rise, it might seem like the abundance of oil (and, to a lesser extent, gas) should be considered a blessing. Countries rich with these natural resources have the opportunity to sell them to external actors and fund their own development from the profits. While this might seem like a perfect scenario without any downsides, the reality proves that this is not always the case. This paper aims to present how natural resources in some Middle Eastern countries might actually be a trap and how in long term they might actually pose a serious threat to their economic growth and stability.

\section{What is a "rentier state"?}

The theory of the "rentier state" was first presented by Hossein Mahdavy, an economist, in a 1970 article "The Patterns and Problems of Economic Development in Rentier States: the Case of Iran". Therein, taking Iran as a model, he identifies rentier states as "those countries that receive on regular basis substantial mounts of external rent ... [which can be defined as] rentals paid by foreign individuals, concerns or governments to individuals, concerns and governments of a given country"1. It is obvious that in the case of Middle Eastern countries most rents come from oil sales. Later in the article the economist argues that the period 1950-1956 constitutes a turning point in the economic history of the Middle East - during that period the political changes enabled the governments of many countries in the region to capture a larger share of the rents which previously accrued to the oil companies. With such

\footnotetext{
${ }^{1}$ H. Mahdavy, The Patterns and Problems of Economic Development in Rentier States: the Case of Iran, [in:] Studies in the Economic History of the Middle East, M. A. Cook (ed.), Oxford University Press, Oxford 1970, p. 428.
}

contribution, the governments could embark on large-scale public expenditure programmes without the need to tax their own people; they also would not suffer from imbalance of payments or high inflation ${ }^{2}$. The rentier state theory was later expanded upon by many other analysts and scholars, including Hazem Beblawi and Giacomo Luciani $^{3}$. It must be noted that former created a definition of a rentier state that is more precise than Mahdavy`s and as such it will be applied to this paper. Beblawi argues that 4 characteristics are required for a country to be called "a rentier state": rent situations predominate the economy; the economy relies on substantial external rent; only a small percentage of the population is involved in the generation of the rent; the government is the principal recipient of the external rent ${ }^{4}$. Although many points of the rentier state theory are still being debated to this day, most of the theorists seem to agree that the rentier state (or "rentier economy" as some prefer) poses several risks. Firstly, the citizens of such countries are virtually dependant on the government and the public structures as they hold all the keys to prosperity. This in turn creates proper conditions for the rise and preservation of authoritarianism. Secondly, the reliance on external rents does not force the countries to undergo significant economic changes and industrialization. This lack of innovation and initiative may cause trouble for future generations.

\section{Oil, gas and state in contemporary Middle East}

Over 40 years after the rentier state theory was first presented, it still holds a great significance for the Middle East and its people. The region remains home to some

\footnotetext{
2 Ibidem, p. 431-432.

3 See: The Rentier State: Nation, State and the Integration of the Arab World, H. Beblawi, G. Luciani (eds), Croom Holm, London 1987.

${ }^{4} \mathrm{H}$. Beblawi, The Rentier State in the Arab World, [in:] The Arab State, G. Luciani (ed.), University of California Press, Berkeley and Los Angeles 1990, p. 87-88.
} 
of the world's biggest oil (and natural gas) producers, as presented in the tables below.

\begin{tabular}{|c|c|c|c|c|c|c|}
\hline $\begin{array}{l}\text { Co } \\
\text { un } \\
\text { try }\end{array}$ & $\begin{array}{l}\text { Pro } \\
\text { ven } \\
\text { oil } \\
\text { rese } \\
\text { rves } \\
\text { (tho } \\
\text { usa } \\
\text { nd } \\
\text { mill } \\
\text { ion } \\
\text { barr } \\
\text { els) }\end{array}$ & $\begin{array}{l}\text { Perc } \\
\text { enta } \\
\text { ge } \\
\text { of } \\
\text { glob } \\
\text { al } \\
\text { oil } \\
\text { rese } \\
\text { rves }\end{array}$ & $\begin{array}{l}\text { Dail } \\
\text { y } \\
\text { pro } \\
\text { duct } \\
\text { ion } \\
- \\
\text { tho } \\
\text { usa } \\
\text { nd } \\
\text { barr } \\
\text { els } \\
(201 \\
2)\end{array}$ & $\begin{array}{l}\text { Perc } \\
\text { enta } \\
\text { ge } \\
\text { of } \\
\text { glob } \\
\text { al } \\
\text { oil } \\
\text { dail } \\
\text { y } \\
\text { pro } \\
\text { duct } \\
\text { ion }\end{array}$ & $\begin{array}{l}\text { Da } \\
\text { ily } \\
\text { ex } \\
\text { po } \\
\text { rts } \\
(2 \\
01 \\
2)\end{array}$ & $\begin{array}{l}\text { Perc } \\
\text { enta } \\
\text { ge } \\
\text { of } \\
\text { glob } \\
\text { al } \\
\text { oil } \\
\text { exp } \\
\text { orts }\end{array}$ \\
\hline $\begin{array}{l}\text { Ira } \\
\mathrm{n}\end{array}$ & $\begin{array}{l}157 . \\
0\end{array}$ & $\begin{array}{l}9.4 \\
\%\end{array}$ & 3680 & $\begin{array}{l}4.2 \\
\%\end{array}$ & - & - \\
\hline $\begin{array}{l}\text { Ira } \\
\mathrm{q}\end{array}$ & $\begin{array}{l}150 . \\
0\end{array}$ & $\begin{array}{l}9.0 \\
\%\end{array}$ & 3115 & $\begin{array}{l}3.7 \\
\%\end{array}$ & - & - \\
\hline $\begin{array}{l}\mathrm{Ku} \\
\text { wai } \\
\mathrm{t}\end{array}$ & $\begin{array}{l}101 . \\
5\end{array}$ & $\begin{array}{l}6.1 \\
\%\end{array}$ & 3127 & $\begin{array}{l}3.7 \\
\%\end{array}$ & - & - \\
\hline $\begin{array}{l}\mathrm{O} \\
\mathrm{ma} \\
\mathrm{n}\end{array}$ & 5.5 & $\begin{array}{l}0.3 \\
\%\end{array}$ & 922 & $\begin{array}{l}1.1 \\
\%\end{array}$ & - & - \\
\hline $\begin{array}{l}\mathrm{Qa} \\
\operatorname{tar}\end{array}$ & 23.9 & $\begin{array}{l}1.4 \\
\%\end{array}$ & 1966 & $\begin{array}{l}2.0 \\
\%\end{array}$ & - & - \\
\hline $\begin{array}{l}\text { Sau } \\
\text { di } \\
\text { Ar } \\
\text { abi } \\
\text { a }\end{array}$ & $\begin{array}{l}265 . \\
9\end{array}$ & $\begin{array}{l}15.9 \\
\%\end{array}$ & $\begin{array}{l}1153 \\
0\end{array}$ & $\begin{array}{l}13.3 \\
\%\end{array}$ & - & - \\
\hline $\begin{array}{l}\text { Syr } \\
\text { ia }\end{array}$ & 2.5 & $\begin{array}{l}0.1 \\
\%\end{array}$ & 164 & $\begin{array}{l}0.2 \\
\%\end{array}$ & - & - \\
\hline $\begin{array}{l}\text { U. } \\
\text { A. } \\
\text { E }\end{array}$ & 97.8 & $\begin{array}{l}5.9 \\
\%\end{array}$ & 3380 & $\begin{array}{l}3.7 \\
\%\end{array}$ & - & - \\
\hline $\begin{array}{l}\mathrm{Ye} \\
\mathrm{me} \\
\mathrm{n}\end{array}$ & 3.0 & $\begin{array}{l}0.2 \\
\%\end{array}$ & 180 & $\begin{array}{l}0.2 \\
\%\end{array}$ & - & - \\
\hline $\begin{array}{l}\text { Ot } \\
\text { her } \\
\mathrm{s}\end{array}$ & 0.6 & $\begin{array}{l}<0.1 \\
\%\end{array}$ & 206 & $\begin{array}{l}0.2 \\
\%\end{array}$ & - & - \\
\hline $\begin{array}{l}\text { Th } \\
\mathrm{e} \\
\mathrm{Mi} \\
\mathrm{ddl} \\
\mathrm{e} \\
\mathrm{Ea} \\
\mathrm{st}\end{array}$ & $\begin{array}{l}807 . \\
7\end{array}$ & $\begin{array}{l}48.4 \\
\%\end{array}$ & $\begin{array}{l}2827 \\
0\end{array}$ & $\begin{array}{l}32.5 \\
\%\end{array}$ & $\begin{array}{l}19 \\
69 \\
9\end{array}$ & $\begin{array}{l}35.6 \\
\%\end{array}$ \\
\hline
\end{tabular}

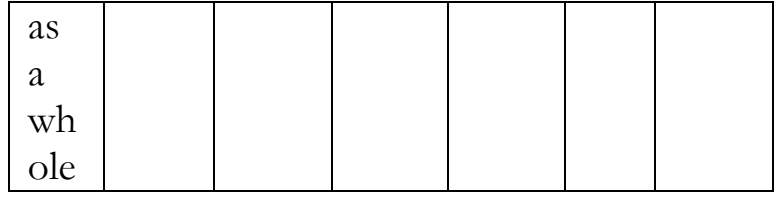

World Energy

[source: BP Statistical Review of June

2013 http://www.bp.com/content/dam/bp/pdf Lstatistical-

review/statistical_review_of_world_energy_ 2013.pdf]

\begin{tabular}{|c|c|c|c|c|c|c|}
\hline $\begin{array}{l}\text { Co } \\
\text { un } \\
\text { try }\end{array}$ & $\begin{array}{l}\text { Pr } \\
\text { ov } \\
\text { en } \\
\text { ga } \\
\text { s } \\
\text { res } \\
\text { erv } \\
\text { es } \\
\text { (tri } \\
\text { llio } \\
\text { n } \\
\text { cu } \\
\text { bic } \\
\text { me } \\
\text { tre } \\
\text { s) }\end{array}$ & $\begin{array}{l}\text { Perc } \\
\text { enta } \\
\text { ge } \\
\text { of } \\
\text { glob } \\
\text { al } \\
\text { gas } \\
\text { rese } \\
\text { rves }\end{array}$ & $\begin{array}{l}\text { Pro } \\
\text { duct } \\
\text { ion } \\
- \\
\text { billi } \\
\text { on } \\
\text { cubi } \\
\text { c } \\
\text { met } \\
\text { res } \\
(201 \\
2)\end{array}$ & $\begin{array}{l}\text { Perc } \\
\text { enta } \\
\text { ge } \\
\text { of } \\
\text { glob } \\
\text { al } \\
\text { gas } \\
\text { pro } \\
\text { duct } \\
\text { ion }\end{array}$ & \begin{tabular}{|l} 
Ex \\
po \\
rts \\
- \\
bill \\
ion \\
cu \\
bic \\
me \\
tre \\
$\mathrm{s}$ \\
$(20$ \\
$12)$
\end{tabular} & $\begin{array}{l}\text { Perc } \\
\text { enta } \\
\text { ge } \\
\text { of } \\
\text { glob } \\
\text { al } \\
\text { gas } \\
\text { exp } \\
\text { orts }\end{array}$ \\
\hline $\begin{array}{l}\mathrm{Ba} \\
\text { hra } \\
\text { in }\end{array}$ & 0.2 & $\begin{array}{l}0.1 \\
\%\end{array}$ & 14.2 & $\begin{array}{l}0.4 \\
\%\end{array}$ & - & - \\
\hline $\begin{array}{l}\text { Ira } \\
\mathrm{n}\end{array}$ & $\begin{array}{l}33 . \\
6\end{array}$ & $\begin{array}{l}18.0 \\
\%\end{array}$ & $\begin{array}{l}160 . \\
5\end{array}$ & $\begin{array}{l}4.8 \\
\%\end{array}$ & - & - \\
\hline $\begin{array}{l}\text { Ira } \\
q\end{array}$ & 3.6 & $\begin{array}{l}1.9 \\
\%\end{array}$ & 0.8 & $\begin{array}{l}<0.1 \\
\%\end{array}$ & - & - \\
\hline $\begin{array}{l}\mathrm{Ku} \\
\mathrm{wai} \\
\mathrm{t}\end{array}$ & 1.8 & $\begin{array}{l}1.0 \\
\%\end{array}$ & 14.5 & $\begin{array}{l}0.4 \\
\%\end{array}$ & - & - \\
\hline $\begin{array}{l}\mathrm{O} \\
\mathrm{ma} \\
\mathrm{n}\end{array}$ & 0.9 & $\begin{array}{l}0.5 \\
\%\end{array}$ & 29.0 & $\begin{array}{l}0.9 \\
\%\end{array}$ & - & - \\
\hline $\begin{array}{l}\mathrm{Qa} \\
\mathrm{tar}\end{array}$ & $\begin{array}{l}25 . \\
1\end{array}$ & $\begin{array}{l}13.4 \\
\%\end{array}$ & $\begin{array}{l}157 . \\
0\end{array}$ & $\begin{array}{l}4.7 \\
\%\end{array}$ & \begin{tabular}{|l|}
12 \\
4.6 \\
\end{tabular} & $\begin{array}{l}12.1 \\
\%\end{array}$ \\
\hline $\begin{array}{l}\text { Sau } \\
\text { di } \\
\text { Ar } \\
\text { abi } \\
\text { a }\end{array}$ & 8.2 & $\begin{array}{l}4.4 \\
\%\end{array}$ & $\begin{array}{l}102 . \\
8\end{array}$ & $\begin{array}{l}3.0 \\
\%\end{array}$ & - & - \\
\hline Syr & 0.3 & 0.2 & 7.6 & 0.2 & - & - \\
\hline
\end{tabular}




\begin{tabular}{|c|c|c|c|c|c|c|}
\hline ia & & $\%$ & & $\%$ & & \\
\hline $\begin{array}{l}\text { U. } \\
\text { A. } \\
\text { E }\end{array}$ & 6.1 & $\begin{array}{l}3.3 \\
\%\end{array}$ & 51.7 & $\begin{array}{l}1.5 \\
\%\end{array}$ & - & - \\
\hline $\begin{array}{l}\mathrm{Ye} \\
\mathrm{me} \\
\mathrm{n}\end{array}$ & 0.5 & $\begin{array}{l}0.3 \\
\%\end{array}$ & 7.6 & $\begin{array}{l}0.2 \\
\%\end{array}$ & - & - \\
\hline $\begin{array}{l}\text { Ot } \\
\text { her } \\
\text { s }\end{array}$ & 0.2 & $\begin{array}{l}0.1 \\
\%\end{array}$ & 2.7 & $\begin{array}{l}0.1 \\
\%\end{array}$ & - & - \\
\hline $\begin{array}{l}\text { Th } \\
\mathrm{e} \\
\mathrm{Mi} \\
\mathrm{ddl} \\
\mathrm{e} \\
\mathrm{Ea} \\
\text { st } \\
\text { as } \\
\text { a } \\
\text { wh } \\
\text { ole }\end{array}$ & $\begin{array}{l}80 . \\
5\end{array}$ & $\begin{array}{l}43.0 \\
\%\end{array}$ & $\begin{array}{l}548 . \\
4\end{array}$ & $\begin{array}{l}16.3 \\
\%\end{array}$ & $\begin{array}{l}15 \\
8.9\end{array}$ & $\begin{array}{l}15.4 \\
\%\end{array}$ \\
\hline
\end{tabular}

[source: BP Statistical Review of World Energy June 2013, http://www.bp.com/content/dambbp/pdf /statistical-

review/statistical_review_of_world_energy_ 2013.pdf]

As one can clearly notice, countries located in the Persian Gulf (Saudi Arabia, Iran, Iraq, Kuwait, U.A.E., Qatar and Oman) benefit greatly, at least in financial terms, from the abundance of oil (together they produce as much as $31.7 \%$ of all the oil in the world). One must remember however, that even though the ratio of production-toconsumption of oil in the Middle Eastern countries is $3.56: 1$, in the case of natural gas it is only 1.42:1. This means that most of the oil produced in the Middle East is exported to other regions, while most of the gas is consumed by the countries themselves. The only notable exception to this rule is Qatar, who is one of the biggest exporters of gas in the world ${ }^{5}$. To fully understand the

5 In 2012 Qatar produced 157 billion cubic metres of gas. Only 26.2 billion (less than 17\%) were consumed by Qataris themselves, while 130.8 billion were exported to other countries, economic situation of those countries as well as their attachment to the production of oil and gas, one must also take into consideration the prices of these resources. The graphs below present the fluctuation of both of those values in the last 20 years.

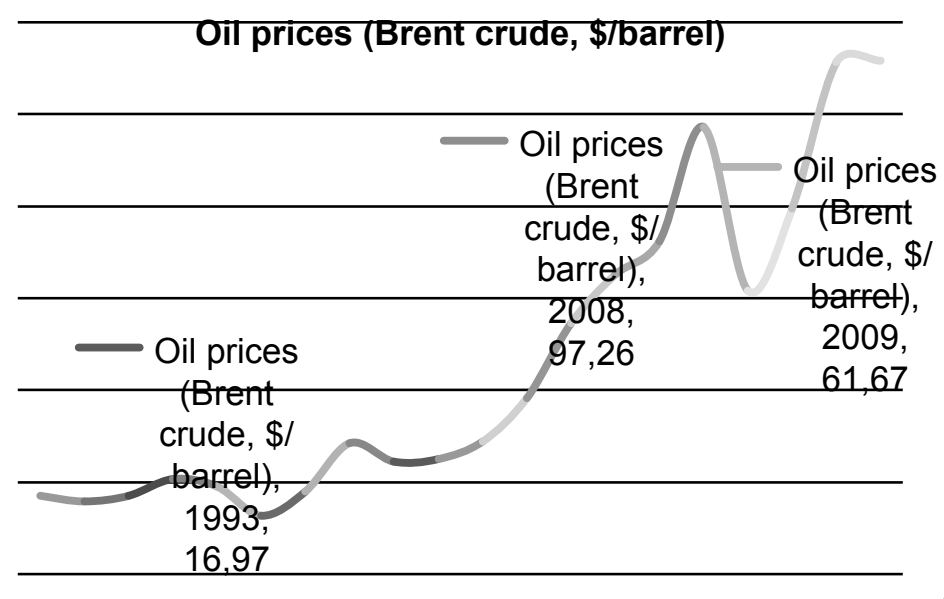

[source: BP Statistical Review of World Energy June 2013, http://www.bp.com/content/dam/bp/pdf/stati stical-

review/statistical_review_of_world_energy_2013 .pdf]

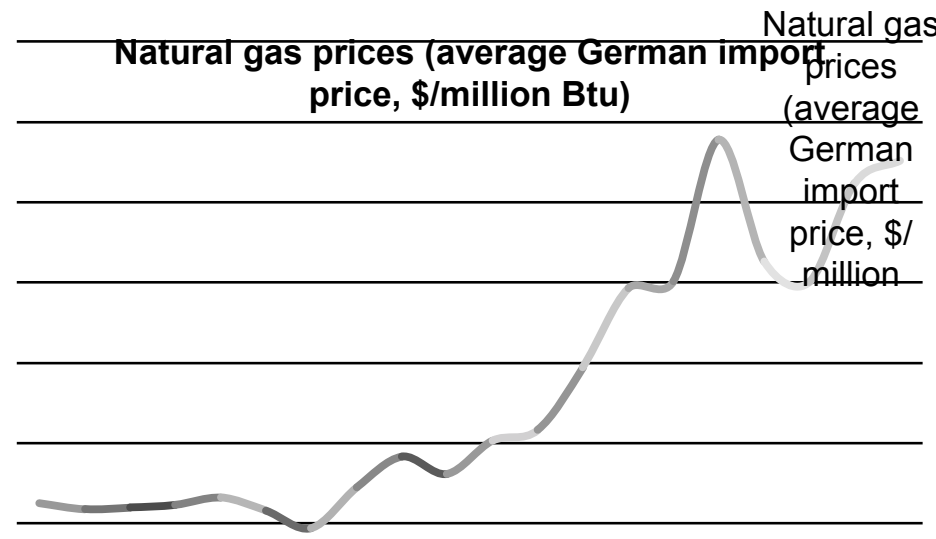

[source: BP Statistical Review of World Energy June 2013, http://www.bp.com/content/dam/bp/pdf /statistical-

including Japan (21.3 billion), India (16.1 billion) and South Korea (14.2 billion). 
review/statistical_review_of_world_energy_ 2013.pdf]

While in the 1990s, both prices were mostly steady, since the beginning of the new millennium, they have been on a sharp rise, with a small exception in 2009 (and 2010 in case of natural gas), which was one of the effects of the global economic crisis. The opportunity to sell natural resources at very high prices has been of great benefit to the countries in the Persian Gulf and has been the biggest contributing factor to their prosperity. In fact, most of them have a high GDP per capita, especially when compared to the poorest countries in the region, like Afghanistan or Syria. surface, it may seem like oil- and gasexporting countries in the Middle East do not have anything to worry about, as far as economic indicators are concerned, the real picture is far from perfect, due to the nature of the rentirer state itself.

\section{The problems}

The biggest problem for the rentier states in the Middle East (which we could now narrow down to the countries located

GDP per capita (US\$) [Middle East]

\begin{tabular}{|c|c|c|c|c|c|c|}
\hline Country & 2008 & 2009 & 2010 & 2011 & 2012 & $\begin{array}{l}\text { Rank (in the world, } \\
\text { either 2010, } 2011 \\
\text { or 2012) }\end{array}$ \\
\hline Arab World (average) & 6105,42 & 5162,56 & 5867,56 & 7017,67 & - & - \\
\hline Afghanistan & 376,98 & 450,66 & 561,20 & 619,59 & - & 172. \\
\hline Bahrain & 19625,58 & 16213,34 & 18334,17 & - & - & 43. \\
\hline Egypt & 2156,76 & 2461,53 & 2803,53 & 2972,58 & 3187,31 & 123. \\
\hline Iran & 4899,31 & 4931,28 & 5674,92 & 6815,57 & - & 80. \\
\hline Iraq & 4472,06 & 3701,86 & 4375,91 & 5686,61 & 6454,62 & 89. \\
\hline Israel & 27591,62 & 26032,16 & 28522,41 & 31281,47 & - & 30. \\
\hline Jordan & 3797,41 & 4027,05 & 4370,72 & 4665,94 & 4945,13 & 100. \\
\hline Kuwait & 54548,62 & 37160,54 & 41566,10 & 56514,16 & - & 9. \\
\hline Lebanon & 7185,61 & 8159,02 & 8551,85 & 9148,13 & 9705,39 & 68. \\
\hline Oman & 23353,17 & 17597,49 & 20640,01 & 23731,21 & - & 34. \\
\hline Qatar & 84628,50 & 62390,28 & 72773,31 & 90523,53 & - & 5. \\
\hline Saudi Arabia & 18064,87 & 14057,62 & 16537,74 & 20777,67 & - & 40. \\
\hline Syrian Arab Republic & 2584,38 & 2564,46 & 2746,85 & - & 3289,06 & 122. \\
\hline $\begin{array}{ll}\text { United } & \text { Arab } \\
\text { Emirates } & \end{array}$ & 46309,98 & 35025,10 & 35259,99 & 40363,16 & - & 25. \\
\hline Yemen & 1238,00 & 1105,82 & 1400,67 & 1361,33 & 1494,43 & 144. \\
\hline
\end{tabular}

[source: World Bank,

http://data.worldbank.org/indicator/NY.G DP.PCAP.CD]

It should be noted that out of 7 Arab states that are above the "Arab World average" only Lebanon is not a major oil/natural gas exporter. Moreover, in case of GDP per capita, Qatar and Kuwait are among the top 10 countries in the world. While on the in the Persian Gulf), as mentioned before, is their utter dependence on oil exports as their major source of revenue. Let us look at some examples. In Saudi Arabia, oil and oilbased products constitute approximately $94 \%$ of all exported goods (or $85 \%$ of all exports, including services), $92.5 \%$ of government revenue ${ }^{6}$ and $50 \%$ of the $\mathrm{GDP}^{7}$.

6 48. Annual Report. The Latest Economic Developments, Saudi Arabia Monetary Agency, p. 
In Iran oil exports make up about $80 \%$ of the country`s total export earnings, $60 \%$ of its government revenue $^{8}$ and $25 \%$ of its GDP 9 . Lastly, in Qatar, the export of oil and gas constitutes $85 \%$ of all its export earnings, $60 \%$ of its GDP and $50 \%$ of government revenue ${ }^{10}$. This has several important consequences.

Firstly, the elites and rulers in the Middle Eastern rentier states have grown accustomed to the fact that they can rely on the external demand for oil (and gas) and that the money gained from the export of these resources is enough to ensure their endurance and control over the country. To this end, many of them have provided welfare and wealth to their citizens, demanding little to nothing in return, other than that they agree to a non-explicit "social contract", which stipulates that they give up their political ambitions and rights ${ }^{11}$. The notion of "no taxation, hence no representation" 12 is not an exaggeration. In fact, in Oman the revenue from taxes

\section{4 ,}

http://www.sama.gov.sa/sites/samaen/Reports Statistics/ReportsStatisticsLib/5600_R_Annual_ En_48_2013_02_19.pdf.

7 Saudi Arabia - National Accounts Indicators 2012, http://www.cdsi.gov.sa/pdf/GDP2012report.p df.

8 Sanctions reduced Iran's oil exports and revenues in 2012,

http://www.eia.gov/todayinenergy/detail.cfm?i $\mathrm{d}=11011$.

${ }^{9}$ Iran Investment Monthly, April and May 2012, p. 8 ,

http://www.turquoisepartners.com/iraninvestm ent/IIM-AprMay12.pdf.

10 Qatar facts and figures, http://www.opec.org/opec_web/en/about_us/ 168.htm.

11 One needs to remember that the situation in Iraq is slightly different - since the 2003 war the country has been trying to become more democratic, with results leaving much to be desired.

12 R. Schwarz, The political economy of state-formation in the Arab Middle East: Rentier states, economic reform, and democratization, "Review of International Political Economy" 15, No. 4, October 2008, p. 607. constitutes only $2.2 \%$ of the GDP and in Kuwait barely $0.7 \%$ of the GDP (to put these numbers in context, in the US it is $10.1 \%$, in France - 21.3\% and in the UK $27.4 \%)^{13}$. As Terry Lynn Karl rightly points out, this means that the governments have no need to build the institutional capacities that have historically been required in resource-scarce countries due to harsher conditions. Moreover, dependence on high oil revenues allows the states to enter and maintain control over many areas of civil life while at the same weakening opportunities to strengthen administrative capacities, merit-based civil services and the rule of law - all of which are indispensable in building efficient state structures and prosperous economy ${ }^{14}$. While authoritarianism in itself is not necessarily harmful to a country`s economic performance (which has been proved by many historic examples, such as China or South Korea), it has to be supported by adequate, stable and reliable administrative structures. These are seldom developed in rentier states.

Secondly, oil dependence has a great impact on the citizens. Although the aforementioned welfare and state-controlled distribution of wealth in the Middle Eastern rentier states do sound promising, it must be remembered that major inequalities do persist. Unfortunately, due to lack of sufficient data it is not possible to come up with the Gini coefficient, which demonstrates how the income distribution among the citizens deviates from perfect equality (results above 0.35 should be considered a significant inequality), for all of these countries. It can be measured, however, for at least some of them: Iraq 30.9 (2007), Iran - 38.3 (2005) and Qatar -

13 Tax revenue (\% of GDP), World Bank, http://data.worldbank.org/indicator/GC.TAX. TOTL.GD.ZS.

14 T. L. Karl, Oil-Led Development: Social, Political, and Economic Consequences, [in:] Encyclopedia of Energy, Volume 4, C. J. Cleveland, R. U. Ayres (eds), Elsevier Academic Press 2004, p. 666. 
$41.1(2007)^{15}$. While it should be noted that these results are not up-to-date and cannot be treated as definitive, it is nonetheless safe to assume that they are representative of the Persian Gulf region. It is especially noteworthy that the country with the highest GDP per capita (Qatar) also has the highest level of inequality and the one with the lowest GDP per capita (Iraq) has got the lowest level of inequality. While these results pale in comparison with the results in countries like Rwanda (Gini coefficient of 50.8 in 2011) or Zambia (57.5 in 2010), they do prove that a Middle Eastern rentier state is not an economically equal state. This should come as no surprise, considering that one sector predominates its entire economy. Moreover, oil-dependence harms the structure of the economy. As more and more people from rural areas move to the cities in hopes of becoming a part of the oil business (not unlike the Dutch disease), the agricultural sector becomes underdeveloped. In fact, the states located in the Persian Gulf are not self-dependent when it comes to food and must import most of it from abroad $^{16}$. It should also be noted that these hopes also attract a lot of foreign workers, who upon arrival not only do not get their dream jobs, but are often mistreated and underpaid. This creates a very bizarre social structure. In Saudi Arabia, for instance, the foreigners constitute about $80 \%$ of its total workforce $^{17}$, while in Qatar an astonishing $94 \%{ }^{18}$ ! With the government being the prime recipient of external rents, it can afford to artificially broaden the public sector and administration and employ most

15 Gini Index, World Bank, http://data.worldbank.org/indicator/SI.POV.G INI?page $=1$.

${ }_{16}$ Z. Babar, Food Security and Food Sovereignty in the Middle East, http://cirs.georgetown.edu/research/grants/11 6115.html.

17 Saudi Arabia - Economy, http://www.saudiarabia.com/Page/Economy/5 9.

18 J. O. Dennie, Modern Slavery: The Plight of Foreign Workers in Qatar, http://digitaljournal.com/article/303006\#ixzz2 djrWV9jl. of its nationals, while a huge majority of the foreigners find jobs in the private sector, usually in services. This causes severe social tensions and problems. It must also be noted that due to the state-provided employment and welfare, the nationals often lack incentive to develop skills necessary for "less lucrative" jobs.

Thirdly, dependence on oil and gas exports makes the rentier states even more vulnerable to drastic changes in the global economy. When the oil price dropped from $97.26 \mathrm{USD} /$ barrel in 2008 to 61.67 USD/barrel in 2009, the countries in the Persian Gulf were severely affected. In just one year the Omani GDP per capita fell by $25 \%$, the Qatari GDP per capita went down by $26 \%$ and the Kuwaiti GDP per capita suffered a decrease of $32 \%$. Even though the prices soared again soon afterwards, it was a drastic and sudden shift. Moreover, even though oil is well known to be a political weapon (as was first proven by OPEC in 1973), it is sometimes forgotten that it can be used by both sides of a dispute. In 2012 the European Union put an embargo on Iranian oil because of the country`s nuclear program. This resulted in diminished exports and a steep drop in Iranian oil revenue - it fell from 95 billion USD (in 2011) to 69 billion USD (in 2012) ${ }^{19}$ - which caused a series of problems for the country`s economy. As one can clearly see, even though oil and gas are usually dependable sources of revenue, over-reliance on these resources can be extremely harmful and dangerous. This lack of what one could call "self-dependence" and the economic issues it may generate, should be regarded with caution by the ruling elites of oilexporting countries, especially considering the events of the so-called Arab Spring. While its effects for the states located in the Persian Gulf were not as serious as for some other countries in the region, it did lead to protests, some governmental changes in Oman and Kuwait and a military intervention of the Gulf Cooperation Council in Bahrain. Even though the

19 Sanctions..., op.cit. 
protests in these countries were mostly motivated by politics and less so by economy (unlike in some other Middle Eastern countries), they proved that the people are unsatisfied with the current situation and way of living. The unrests may be slowly dying off, but possible economic problems, caused by over-dependence on oil exports and the instability of world economy, could bring them back to life in the future.

Fourthly, as Hazem Beblawi points out, the politics of the rentier state has affected not only the oil/gas-exporting countries themselves, but other countries in the region as well, turning them into "semirentiers without oil". As much of their own GDP is comprised of external rent-like revenues (royalties, workers ' remittances, foreign aid etc.), they also adopted some of the rentier state's behavior and elements, such as overblown bureaucracy ("a new rentier class"), which serves to guarantee that the people employed by the state do not turn against their own employer and remain loyal ${ }^{20}$.

Finally, and perhaps most importantly, one has to wonder about the long-term future of Middle Eastern rentier states. While for now they can rely on oil and gas as their primary source of revenue, these resources are eventually going to run out. The only question remains, when? Some scientists believe that at present rates of consumption, the current reserves will be sufficient for the next 40 years in case of oil and 60 years in case of natural gas ${ }^{21}$. These claims are of course purely estimative and do not take into consideration the emergence of new technologies or the discovery of new reservoirs. One must also remember that many of past predictions regarding that subject have been proven wrong ${ }^{22}$. However,

\footnotetext{
${ }^{20}$ Beblawi, op. cit., p. 95-98.

21 Are We Running Out of Oil and Gas?, http://www.petrostrategies.org/Learning_Cente r/are_we_running_out_of_oil_and_gas.htm.

22 For example, in 1950 geologists estimated the world's total oil endowment at around 600 billion barrels. Current estimates put that number at almost 1.7 trillion barrels. See: Are we
}

oil and gas are definitely not going to last forever and even if we remain optimistic, it is safe to assume that these resources will get exhausted either by the end of this century or by the beginning of the next one ${ }^{23}$. Considering that non-oil (non-gas) sectors of the economies of the Middle Eastern rentier states are hugely underdeveloped and that the majority of their products and services are rather uncompetitive on the global market, the economic future of these countries could be bleak.

\section{Towards a post-rentier state in the Middle East?}

It is obvious by now that economic growth should not be regarded in purely financial terms, just as a measurement of GDP or GDP per capita rise. The real progress demands serious changes in the structure of the economy itself, selfreliability and the development of human capital. Instead, the rentier state promotes economic immobility and lack of innovation. Dependence on oil and gas sales may be convenient for the ruling elites and many citizens in these countries, but it is becoming more and more apparent that the rentier state practices are a serious obstacle to real development.

Fortunately, the decision-makers in the Middle Eastern rentier states have not been oblivious to these problems and have been trying to modify their economic policies for some time. The results of these actions vary from country to country. Matthew Gray argues that the model currently represented by the Arab states of the Gulf should be referred to as "late rentier". In said model, "the state is more entrepreneurial, supportive of development,

running out of oil? Policy Backgrounder No. 159, http://www.ncpa.org/pdfs/bg159.pdf.

${ }^{23}$ It is interesting to note that the Middle East as a region has the second highest oil-reserves-toproduction ratio in the world (behind South and Central America) and the highest gas-reservesto-production ratio. 
and responsive than it was previously" 24 . Saudi Arabia, for instance, has been trying to develop its private sector and has invested in infrastructure and education ${ }^{25}$. It is estimated that the growing private sector is now generating over $40 \%$ of the country`s GDP. Other examples can be given. Qatar tries to diversify its economy into a more sustainable model, including global financial investments, the creation of tourism and sporting event destinations, a world-class carrier in Qatar Airways, and the creation of a global financial hub ${ }^{26}$. These new positive changes are less visible in Iran and Iraq, two Middle Eastern rentier states who have been dealing with serious international problems for quite some time.

But even these developments are still insufficient and too slow - the very nature of rentierism in said countries persists. Strengthening the private sector and diversifying the economy may also lead to consequences that could be considered "unwanted" by the ruling autocratic elites namely, the development of a civil society that is fully aware of the political rights it is entitled to. The growing calls for democratization could pose a threat to the current rulers' grip over their countries. That, in turn, may discourage them from entirely abandoning the rentier state practices.

\section{Conclusion}

${ }^{24}$ M. Gray, A Theory of "Late Rentierism" in the Arab States of the Gulf, Occasional Paper No. 7, Center for International and Regional Studies, Doha 2011, p. 23.

${ }^{25}$ IMF: Private sector may not keep pace with Saudi youth bulge, http://www.gmanetwork.com/news/story/319 059/economy/business/imf-private-sector-maynot-keep-pace-with-saudi-youth-bulge.

${ }^{26}$ Qatar looks to diversify its economy away from bydrocarbon export reliance, http://www.ameinfo.com/qatar-looks-diversifyeconomy-hydrocarbon-export-318995.
The abundance of oil and gas in the countries located in the Persian Gulf is both a blessing and a curse. While the export of these resources plays a substantial role in their nominal economic growth, it also paves the way for negative practices of a rentier state, which include over-reliance on said resources, static economy, inflated bureaucracy and preservation of authoritarianism. Since excessive attachment to this model might prove disastrous in the future, many states have initiated new policies aiming to diversify their economic structures, strengthen the private sector and attract foreign non-oil/gas related investments. These reforms, though necessary, are still far too conservative. If the policy-makers in the countries located in the Persian Gulf really wish to secure their states` future, they will have to take bolder and more radical actions.

\section{References}

48. Annual Report. The Latest Economic Developments, Saudi Arabia Monetary Agency, http://www.sama.gov.sa/sites/samaen/Rep ortsStatistics/ReportsStatisticsLib/5600_R_ Annual_En_48_2013_02_19.pdf.

Are we running out of oil? Policy
Backgrounder
No.
http://www.ncpa.org/pdfs/bg159.pdf.

Are We Running Out of Oil and Gas?, http://www.petrostrategies.org/Learning_C enter/are_we_running_out_of_oil_and_gas. htm.

Babar Z., Food Security and Food
Sovereignty in the Middle East, http://cirs.georgetown.edu/research/grants /116115.html.

Beblawi H., The Rentier State in the Arab World, [in:] The Arab State, Luciani G. (ed.), University of California Press, Berkeley and Los Angeles 1990, p. 85-98.

BP Statistical Review of World Energy, June 2013, 
http://www.bp.com/content/dam/bp/pdf /statistical-

review/statistical_review_of_world_energy_ 2013.pdf

Dennie J. O., Modern Slavery: The Plight of Foreign Workers in Qatar, http://digitaljournal.com/article/303006\#ix zz2djrWV9j1.

Gray M., A Theory of "Late Rentierism" in the Arab States of the Gulf, Occasional Paper No. 7, Center for International and Regional Studies, Doha 2011.

IMF: Private sector may not keep pace with Saudi youth bulge, http://www.gmanetwork.com/news/story/ 319059/economy/business/imf-privatesector-may-not-keep-pace-with-saudi-youthbulge.

2012,

Iran Investment Monthly, April and May http://www.turquoisepartners.com/iraninve stment/IIM-AprMay12.pdf.

Karl T. L., Oil-Led Development: Social, Political, and Economic Consequences, [in:] Encyclopedia of Energy, Volume 4, Cleveland C. J., Ayres R. U. (eds), Elsevier Academic Press 2004, p. 661-672.

Mahdavy H., The Patterns and Problems of Economic Development in Rentier States: the Case of Iran, [in:] Studies in the Economic History of the Middle East, Cook M. A. (ed.), Oxford University Press, Oxford 1970, p. 428-467.

Qatar facts and figures, http://www.opec.org/opec_web/en/about _us/168.htm.

\footnotetext{
Qatar looks to diversify its economy away from bydrocarbon export reliance, http://www.ameinfo.com/qatar-looksdiversify-economy-hydrocarbon-export318995.

Sanctions reduced Iran's oil exports and revenues in 2012 ,
}

http://www.eia.gov/todayinenergy/detail.cf m?id=11011.

Saudi Arabia - Economy, http://www.saudiarabia.com/Page/Econo my/59.

Indicators

Saudi Arabia - National Accounts http://www.cdsi.gov.sa/pdf/GDP2012repo rt.pdf.

Schwarz R., The political economy of state-formation in the Arab Middle East: Rentier states, economic reform, and democratization, "Review of International Political Economy" 15, No. 4, October 2008, p. 599621.

World

Bank,

http:/ / data.worldbank.org. 